\title{
Ülkelerin Yükseköğretim Performanslarının Bulanık C-Ortalamalar Kümeleme Algoritması ile Değerlendirilmesi
}

\author{
Abdulkerim Çalışkan', Deniz Koçak², Yasin Ertürk' \\ 'Ankara Hacı Bayram Veli Üniversitesi, Iktisadi ve Idari Bilimler Fakültesi, Maliye Bölümü, Ankara \\ ${ }^{2}$ Osmaniye Korkut Ata Üniversitesi, Iktisadi ve Idari Bilimler Fakültesi, Ekonometri Bölümü, Osmaniye \\ ORCID: A. Çalışan (0000-0003-3123-8890), D. Koçak (0000-0002-5893-0564), Y Ertürk (0000-0003-3809-2919)
}

\begin{abstract}
Özet
Yükseköğretim, bireylerin uzmanlaşarak belirli alanlarda faaliyet göstermeye başlamasına ortam hazırlaması bakımından eğitim sistemi içerisinde oldukça önemli bir yere sahiptir. Her ülke yükseköğretim yapısını kendi sosyal ve kültürel değerlerini de katarak çağın gereksinimlerine cevap verebilecek şekilde dizayn etme amacındadır. Bu kapsamda Türkiye'nin yükseköğretim sisteminin var olan mevcut sorunlarına rağmen süreç içerisinde önemli bir gelişme gösterdiğini ifade etmek yerinde olacaktır. Bu çalısmada bulanık c-ortalamalar kümeleme algoritması kullanılarak, seçilen 32 ülkenin yükseköğretim performanslarına göre gruplandırılması amaçlanmışır. Ülkelerin yükseköğretim performansları, eğitim, istihdam ve ekonomi kategorilerinde seçilen değişkenler aracılığıyla kümeleme algoritmasında analiz edilmiştir. Çalışma sonucunda Norveç ve İsviçre ile birlikte AB üye ve aday ülkeleri (Türkiye, Kuzey Makedonya, Sırbistan) dört küme içerisinde gruplandırılmışıır. Bu kümeler aracılığılla yükseköğretim performansları bakımından benzer niteliklere sahip olan ülkeler birlikte değerlendirilmiş ve ilgili ülkelerin yükseköğretim rekabet edebilirlikleri karşılaştırılmıştır. Karşış̧sırımalar sonucunda ülkelerin yükseköğretim sistemlerine ilişkin birtakım çıkarımlar yapılmış ve Türkiye'nin mevcut durumu ile birlikte bu durumunun iyileştirilmesine yönelik çeşitli öneriler sunulmuştur.
\end{abstract}

Anahtar kelimeler: yükseköğretim; kümeleme algoritması; bulanık c-ortalamalar.

\section{Assessment of Countries' Higher Education Performances with Fuzzy C-Means Clustering Algorithm}

\begin{abstract}
Higher education has a very important place in the education system in terms of preparing an environment for individuals to specialize and start operating in certain areas. Each country aims to design its higher education structure in a way that can meet the needs of the age by adding its own social and cultural values. In this context, it would be appropriate to express that showed a significant improvement in existing processes, despite the current problems of Turkey's higher education system. This study is aimed to group 32 selected countries according to their higher education performances using the fuzzy c-means clustering algorithm. The higher education performances of the countries were analyzed in the clustering algorithm through the variables selected in education, employment, and economy categories. As a result of the study, the EU member and candidate countries (Turkey, Northern Macedonia, Serbia), together with Norway and Switzerland, were grouped into four clusters. Through these clusters, countries have been evaluated together with countries that have similar qualifications in terms of higher education performance, and the higher education competitiveness of the relevant countries has been compared. Thanks to the comparisons, some inferences were made regarding the higher education systems of the countries, and along with the current situation of Turkey, various suggestions have been presented to improve this situation.
\end{abstract}

Keywords: higher education; clustering algorithm; fuzzy c-means.

\section{GiRiş}

"Eğitimimizi tamamladığımızı söylemeye asla ihanet etmeyelim; çünkü bu gelişmeyi bıraktığımız anlamına geliyor.”

Julia H. Gulliver

*Yazışma Adresi / Address for Correspondence:

A. Çalışkan, Email: abdulkerim.caliskan@hbv.edu.tr

Geliş Tarihi / Received Date: 16.03.2021

Kabul Tarihi / Accepted Date: 22.03.2021

Doi: 10.26701/uad.898187
Yükseköğretim kurumlarının çeşitli açılardan farklı amaçları vardır ve bu amaçlar ülkeler özelinde farklılıklar gösterebilmektedir. Ancak bilgi üretmek, eğitim vererek nitelikli bir toplum yapısı geliștirmek ve beșeri sermayeye yönelik hizmetler ortaya koymak her yükseköğretim sisteminin temel amaçları arasında yer almaktadır (Çavdar, 1994, ss.3-4). Yükseköğretim ile ilgili yapılan çalışmalar ve hazırlanan raporlarda genel olarak Amerika ön plana çıssa da Avrupa ülkeleri ile birlikte Çin, Rusya, Japonya ve İskandinav ülkelerindeki yapı da giderek gelişmekte ve bu ülkeler de farklı yapılar ortaya koymaktadır. Söz konusu farklılıklar yükseköğretim 
öncesi eğitim sisteminin mevcut yapısı, ekonomik ve mali açılardan eğitime ayrılan paylar, fırsat eşitliği, katılımcı yapı, bağımsızlık, şeffaflık ve denetlenebilir olma gibi uluslararası geçerliliğe sahip olan ilkelerden kaynaklanmaktadır. Bu ilkelerin gereklerini yerine getiren sistemlerde güçlü ve nitelikli bir yükseköğretim yapısı oluşmakla birlikte, ilkelerin gereklerini çeşitli nedenlerle yerine getiremeyen ülkelerde zayıf bir sistem ortaya çıkmaktadır (Küçükcan ve Gür, 2010, ss.16-17).

Bilgi toplumunun bir sonucu olarak kamusal hizmetlerin niteliğinde meydana gelen dönüşüm, ülkelerin yükseköğretim sisteminde önemli yapısal değişikliklere ortam hazırlamıştır. Buna bağlı olarak ülkeler küresel düzeydeki rekabeti artırma amacıyla, yükseköğretimlerinde reform niteliğinde uygulamalar yapma gayreti içerisinde olmuşlardır (Deem, Mok ve Lucas, 2008, s.83). Bu reformlar aracılığıyla her ülke üniversitelerinin uluslararası sıralamalarda daha iyi konuma gelmesi için çaba sarf etmektedir. Günümüzde de üniversitelerin sıralanması konusu ön plana çıkmış ve sıralama konusunda çok sayıda endeks türetilmiştir (International Ranking Expert Group, 2006). Aynı zamanda içinde bulunduğumuz bilgi çağı düşünüldüğünde yükseköğretim sisteminin önemi daha çok ortaya çıkmaktadır. Bu kapsamda üniversitelerin her alanda nitelik olarak geliştirilmesi ve sorunlarının giderilmesi gerekmektedir. Ancak bu şekilde kalifiye bireylerden meydana gelen güçlü bir beşeri sermayeye sahip olunması mümkün olacaktır.

Türkiye'de yükseköğretim sisteminin tarihçesi çok eskilere dayanmaktadır. Nitekim ülkemizdeki sistem önemli dönüşümler geçirmiştir. Osmanlı dönemi ile cumhuriyet döneminde farklı yapılar söz konusudur. Ancak bugüne kadar gelinen süreçte nitelik ve nicelik açısından gelişim süreci devam etmektedir (Gedikoğlu, 2005, s.74). Yükseköğretim sistemi sosyo-ekonomik yapıdaki değişimlere uyum sağlaması ve toplumun gelişmesine öncülük etmesi açısından sürekli bir devinim ve gelişim içinde olmalıdır. Aksi takdirde yükseköğretim politikalarından istenilen sonuç alınamayacaktır. Bu çerçevede özellikle yabancı ülkelerdeki sistemler analiz edilerek ülkemizdeki üniversitelerin uluslararası raporlar ve kıyaslamalarda üst sıralara çıkarılması gerekmektedir. Bu da ancak sistemin her alanda niteliğinin artırılması ile mümkün olacaktır. Son yıllarda ülkemizdeki durum incelendiğinde ise öğretim eleman alımına ilişkin yapılan düzenlemeler ile üniversitelerin politik münazaralardan ve kutuplaşmadan uzaklaştığı, liyakati esas alan akademisyen atamalarının iyi bir düzeye geldiği görülmektedir. Zaman içerisinde de bu iyileştirme sürecinin ileriye taşınması beklenmektedir. Ayrıca ülkemizdeki norm kadro uygulaması ile ihtiyaç duyulan alanların da etkinliği sağlanmıştır. Bu sayede yükseköğretimimizde nitelik açısından önemli düzenlemeler yapılmıştır. Buradan da anlaşılacağı üzere yükseköğretim sistemimizde uluslararası standartların yakalanması elzemdir (Çömlekçi, 1971, s.69). Günümüzde teknoloji ve bilgi yoğun sektörlerin artan önemi göz önünde bulundurulduğunda, bu alanlarda doktoralı mezun sayımızın artırılması yerinde olacaktır. Bununla birlikte üniversitelerdeki mevcut sorunların çözülerek akademisyen kanadında da efektif bir çalışma ortamı oluşturulmalıdır. Aksi takdirde akademiye nitelikli eleman yetiştirmek zorlaşacaktır. Bunun sonucunda ülkenin eğitim sistemi uzun vadede belirli bazı sorunlarla karşı karşıya kalacaktır. Bir diğer önemli konu yükseköğretim sisteminde evrensel standartların yakalanması, üniversal düzeyde bilgi üretiminin sağlanması gibi hedeflerin yanı sıra sistemin toplumsal ve milli değerlerimizle düzenlenmesi konusudur. Burada üniversitelerin siyasi yapılanmalardan arındırılması da yükseköğretim sistemimizin kronikleşen sorunları arasında yer almaktadır (Adem, 1982, s.71).

Ülkelerin yükseköğretim yapıları kendi koşulları içerisinde şekillendiğinden belirli düzeyde farklılıklar göstermektedir. Doğal olarak yükseköğretimden mezun olan kişilerin yeterlilikleri de işgücü piyasası içinde farklılıklar göstermektedir (Joumady ve Ris, 2005, s.189). Burada en büyük sorunların başında üniversiteler ile iş dünyası arasında nitelikli bir ilişkinin kurulamamış olmasıdır gelmektedir. Mühendislik fakülteleri özelinde durum değerlendirildiğinde teori ve uygulama konusunda belirli yetersizlikler söz konusudur. Bu da gerek üniversitelere gerekse iş dünyasına zarar vermektedir. Mevcut durumun yalnızca yükseköğretim kurumları çerçevesinde ele alınması yanlış olacaktır. Nitekim meslek liseleri ve meslek yüksekokullarını da kapsayacak bir eylem planının yapılması yerinde olacaktır (Küçükcan ve Gür, 2010, s.19).

Yükseköğretim sistemine yapılan harcamalar her geçen dönem artış göstermektedir. Bu artışın temel nedeni dünya genelinde yükseköğretim görmek isteyen kişi sayısının artmasıdır. Bireylerin bu yöndeki ihtiyaç ve isteklerinin karşılanmasının maddi bir boyutu söz konusudur. Zaman içerisinde özel sektörün devreye girmesi devleti mali yükümlülükler konusunda rahatlatsa da dünya genelinde devletlerin her yıl bütçelerinde eğitime ayırdıkları paylar artış eğilimi içerisindedir. Bu durum fırsat eşitsizliği açısından bazı tartışmaları beraberinde getirse de rekabet ortamının oluşması yükseköğretim sistemine olumlu yönde bir etki yapacaktır. Ancak rekabet koşullarının da eğitimde fırsat eşitliğine aykırı sonuçlar doğurmasının önüne geçilmesi gerekmektedir. Zira eğitim öğretim faaliyetlerinin tamamen özel sektöre bırakılması toplumun belirli bir kesiminin bu hizmetten faydalanamamasına neden olacaktır (Çalışkan, 2001, s.256) Şüphesiz eğitim harcamaları, ekonomik büyüme ve kalkınmanın iyileştirilmesinde önemli bir işleve sahip olup, büyüme performansını ciddi oranda artırmaktadır. Bunun en temel örneği ise daha eğitimli işgücüne sahip nispeten gelişmiş ülkelerin, 1960 sonrasında hızlı bir büyüme eğilimine girmiş olmalarıdır (Gemmell, 1998, s.133). Devlet tarafından gerek bütçe ile eğitime ayrılan pay gerekse özel sektör faaliyetlerini destekleyen teşvik- 
ler, her alanda nitelikli bireylerin yetişmesine ortam hazırlamıştır. Bunun doğal bir sonucu olarak ülkeler hızlı bir kalkınma sürecine girmişlerdir. Eğitimin kalkınma ile doğrudan ilişkisi göz önüne alındığında ülkelerin kalkınmışlık düzeylerini artırmak için eğitime daha fazla pay ayırmalarını gerektiğini ifade etmek yanlış olmayacaktır (Çalışkan, 2001, s.251).

Yükseköğretim sisteminin geçirmiş olduğu dönüşümün sonucunda uluslararası düzeyde Avrupa Yükseköğretim Alanı (AYA) kurulmuştur. Bu oluşumun amacı yükseköğretim sistemi ile ilgili olarak yukarıda bahsedilen sorunların çözülmesi ve yüksek nitelikli bir sistemin inşa edilmesidir. Burada özellikle Bologna sürecinin de üzerinde durulması gerekmektedir. Zira Bologna süreci ülkelerin yükseköğretim sistemlerinin belli standartlarda karşılaştırma yapılmasına imkân sağlayarak içinde bulunulan mevcut durumun görülmesine ve uygulanan politikalarının etkinliğine yönelik fikirler sağlaması açısından önem arz etmektedir. 29 ülke ile başlayan Bologna süreci günümüz itibariyle 48 ülkeye ulaşmıştır. Bologna süreci, kolay anlaşılabilir ve karşılaştırmaya elverişli bir sistemin oluşturulması, Avrupa Kredi Transfer Sistemi'ne (AKTS) geçilmesi, öğrenci ve öğretim elemanlarının hareketliliğin teşvik edilmesi ve kalite güvence sisteminin oluşturulması gibi temellere dayanmaktadır (Büyükgöze ve Özdemir, 2016, s.41).

Yükseköğretim sisteminin temel yapısı ve sorunlarına ilişkin değerlendirmelerin daha da detaylandırılması mümkündür. Ancak bu çalışma eğitim, istihdam ve ekonomi alanında seçilen tematik değişkenler özelinde bir durum değerlendirmesi yapmayı amaçlamaktadır. Bu doğrultuda çalışmanın izleyen bölümlerinde, ülkelerin yükseköğretim performanslarının değerlendirilmesinde başvurulan yöntem olan bulanık c-ortalamalar (Fuzzy c-means (FCM)) kümeleme algoritmasına, bu algoritmada kullanılmak üzere oluşturulan veri setine ve kümeleme sonucunda elde edilen bulgulara yer verilecektir. Çalışma, ülkelerin yükseköğretim performanslarının değerlendirilmesinde FCM kümeleme algoritmasından elde edilen bulguların değerlendirilmesi ve önemli sonuçların verilmesiyle sonlandırılmaktadır.

\section{YÖNTEM}

\subsection{Bulanık C-Ortalamalar Kümeleme Algoritması}

Kümeleme algoritmaları, verileri benzerliklerine göre s1nıflamak için kullanılan denetimsiz öğrenme algoritmalarındandır (Sefidian ve Daneshpour, 2019). Dunn (1973) tarafından tanıtılan ve Bezdek (1981) tarafından geliştirilen FCM, bulanık mantığa dayalı denetimsiz kümeleme algoritmalarındandır. Görüntü analizi, hedef tanıma, mühendislik gibi alanlara başarıyla uygulanan bu algoritma, en önemli ve popüler kümeleme algoritmalarından kabul edilmektedir (Ghosh ve Dubay, 2013).

$X=\left\{x_{i}, i=1,2, \ldots, n \mid x_{i} \in \mathbb{R}^{d}\right\}$ veri noktaları kümesi olmak üzere, $i$. veri noktası vektörünün $d$ boyutlu vektörü $x_{i}$ ile gösterilsin. Buna göre $n$ vektörlü veri noktaları kümesi, (1) eşitliğindeki gibi oluşturulmaktadır:

$$
X=\left[\begin{array}{ccc}
x_{11} & \cdots & x_{1 d} \\
\vdots & \ddots & \vdots \\
x_{n 1} & \cdots & x_{n d}
\end{array}\right]
$$

FCM kümeleme algoritması, $X$ veri noktaları kümesini $U$ üyelik matrisi yardımıyla $c$ sayıda örtüşen kümeye ayırmaktadır. Bu algoritmada bir kümeye üyelik için minimum bir gereksinim belirlenir ve veri noktaları belirlenen bu minimum uzaklığg karşılarsa birden fazla kümeye ait olabilmektedirler (Al Kindhi, Sardjono, Purnomo ve Verkerke, 2019). Dolayısıyla $U$ üyelik matrisi, her bir $k(k=1,2, \ldots, c)$ kümesindeki $x_{i}$ veri noktası vektörünün üyelik derecelerinden oluşan bir matrisi ifade etmektedir. $i$. veri noktası vektörünün $k$. kümedeki üyelik derecesi ise $\mu_{i k} \in U$ olmak üzere üyelik matrisi (2) eşitliğindeki gibi oluşmaktadır:

$$
U=\left[\begin{array}{ccc}
\mu_{11} & \cdots & \mu_{c 1} \\
\vdots & \ddots & \vdots \\
\mu_{1 n} & \cdots & \mu_{c n}
\end{array}\right]
$$

Yukarıda $\forall i, k$ için $\mu_{i k} \in[0,1]$ 'dir. Aynı zamanda bu üyelik derecesi, $\forall k$ için $\sum^{c} \mu_{i k}=1$ ve $\forall i$ için $0<\sum_{k=1}^{n} \mu_{i k}<n$ 'dir. $c$ kümesi ve $n$ veri noktalarını içeren kümeleme için bulanık üyelik dereceleri matris ailesi yani $M_{f c}$ ise aşağıdaki eşitlikte verilmektedir:

$$
M_{f c}=\left\{U \in \mathbb{R}^{c \times n} \mid \mu_{i k} \in[0,1], \forall i, k ; \sum_{i=1}^{c} \mu_{i k}=1, \forall k ; 0<\sum_{k=1}^{n} \mu_{i k}<n, \forall i\right\}
$$

FCM kümeleme algoritması, $J_{m}(U, v)$ amaç fonksiyonunun yerel olarak minimumunu içeren yinelemeli bir optimizasyon problemine dayanmaktadır.

$$
J_{m}(U, v)=\sum_{k=1}^{n} \sum_{i=1}^{c} \mu_{i k}{ }^{m} d_{i k}{ }^{2}
$$

Yukarıdaki amaç fonksiyonundaki $v$ paramatresi küme merkezini ifade etmektedir. Diğer bir ifadeyle $V=\left\{v_{i}, i=1,2, \ldots, c \mid v_{i} \in \mathbb{R}^{d}\right\}$ olmak üzere, i. küme merkezi olan $v_{i}, d$ boyutlu bir vektörü ifade etmektedir. Amaç fonksiyonundaki $m(m>1)$ parametresine bulanıklaştırıcı (fuzzifier) denmektedir. Bu parametre kümelerin örtüşme derecesini belirlemektedir. Diğer taraftan $d_{i k}=x_{k}-v_{i}$ ise veri noktası $x_{k}$ ve $i$. küme merkezi $v_{i}$ arasındaki Öklid uzaklık ölçüsünü ifade etmektedir. Bu uzaklık ölçüsü aşağıdaki eşitlik kullanılarak hesaplanmaktadır.

$$
d_{i k}=d\left(x_{k}-v_{i}\right)=x_{k}-v_{i}=\left[\sum_{j=1}^{m}\left(x_{k j}-v_{i j}\right)^{2}\right]^{1 / 2}
$$

Yinelemeli optimizasyon yöntemi olan FCM aşağıdaki adımlardan oluşmaktadır (Ross, 2010, ss.352-353; Izakian ve Abraham, 2011, s.1836):

Adım 1. $m(m>1)$ bulanıklaştırıcı ve $c(2 \leq c<n)$ küme sayısı belirlenir. $U^{(0)} \in M_{f c}$ olmak üzere, $U$ matrisi başlatılır.

Adım 2. $\left\{v_{i}^{(r)}\right\},(r=0,1, \ldots)$ küme merkezi aşağıdaki eşitlik kullanılarak hesaplanır: 


$$
v_{i j}^{(r)}=\frac{\sum_{k=1}^{n} \mu_{i k}{ }^{m} x_{k j}}{\sum_{k=1}^{n} \mu_{i k}{ }^{m}}
$$

Adım 3. $\left\{d_{i k}^{(r)}\right\},(r=0,1, \ldots)$ Öklid uzaklıkları hesaplanır.

Adım 4. $U^{(r)}$ matrisi $r$. adım için aşağıdaki eşitlik kullanılarak güncellenir:

$$
\mu_{i k}^{(r+1)}=\left[\sum_{j=1}^{c}\left(\frac{d_{i k}^{(r)}}{d_{j k}^{(r)}}\right)^{2(m-1)}\right]^{-1}, i=1, \ldots, n, k=1, \ldots, c
$$

Adım 5. Eğer $U^{(r+1)}-U^{(r)} \leq \varepsilon$ ise durulur; değilse Adım 2'ye dönülür.

\subsection{Veri Seti}

Araştırmanın veri seti, 2017 - 2018 yıllarında ülkelerin yükseköğretimleri seviyesindeki eğitim, istihdam ve ekonomi kategorilerinde seçilen çeşitli değişkenlerinin derlenmesi sonucunda olușturulmuştur. Bu kapsamda eğitim kategorisinde yükseköğretim mezun sayısı, yükseköğretimdeki öğretim kadrosu ve yine aynı seviyedeki öğrenci - akademik personel oranı değișkenleri kullanılmıștır. İstihdam kategorisinde günümüz beșeri sermayenin ve ekonominin merkezinde kabul edilen bir değișken olarak teknoloji ve bilgi yoğun sektörlerdeki istihdam sayısı değişkeni kullanılmıştır. Son olarak ekonomi kategorisinde ise Ar-Ge için ayrılan GSYİH'den ayrılan harcama ve yükseköğretim seviyesi için yapılan harcama değişkenleri kullanılmıştır. Bu anlatılanlar kapsamında kümeleme algoritmasında kullanılan değişkenler açıklamaları, birimleri ve ait oldukları yıllar itibariyle detaylı olarak Tablo 1'de verilmiştir.

\begin{tabular}{|c|c|c|c|}
\hline $\begin{array}{l}\text { Kate- } \\
\text { gori }\end{array}$ & Değişken & Birim & Yll \\
\hline \multirow{3}{*}{ Eğitim } & $\begin{array}{c}\text { Doğa bilimleri, matematik ve istatistik, } \\
\text { bilgi ve iletişim teknolojileri, mühen- } \\
\text { dislik, imalat ve inşaat alanlarında } \\
\text { yükseköğretim mezunu }\end{array}$ & $\begin{array}{c}\text { 20-29 yaş arası } \\
\text { bin kişi başına } \\
\text { düşen sayı }\end{array}$ & 2018 \\
\hline & Yükseköğretimdeki öğretim kadrosu & Bin kişi & 2018 \\
\hline & $\begin{array}{l}\text { Yükseköğretimdeki öğrenci - akademik } \\
\text { personel oranı }\end{array}$ & $\begin{array}{c}\text { Akademik perso- } \\
\text { nel başına düşen } \\
\text { öğrenci sayısı }\end{array}$ & 2018 \\
\hline $\begin{array}{l}\text { İstih- } \\
\text { dam }\end{array}$ & $\begin{array}{c}\text { Ulusal düzeyde teknoloji ve bilgi yoğun } \\
\text { sektörlerdeki istihdam }\end{array}$ & Bin kişi & 2018 \\
\hline \multirow{2}{*}{$\begin{array}{l}\text { Ekono- } \\
\text { mi }\end{array}$} & Ar-Ge için ayrılan GSYiH & $\%$ & 2018 \\
\hline & $\begin{array}{l}\text { GSYiH'ye göre yükseköğretim için } \\
\text { yapılan kamu harcaması }\end{array}$ & $\%$ & 2017 \\
\hline
\end{tabular}

Tablo 1. Kümeleme Algoritmasında Kullanılan Değişkenler

Tablo 1'de sunulan değişkenlerden Ar-Ge için ayrılan GSYH değişkeni OECD'den diğer tüm değişkenler Eurostat'tan derlenerek kümeleme algoritmasına dâhil edilmiştir., ${ }^{1,2}$ Diğer taraftan istihdam ve Ar-Ge değișkenleri dışındaki tüm değişkenlerin de yükseköğretim seviyesinde yani ISCED 5-8 seviyelerinde oldukları görülebilmektedir. Uluslararası Eğitim Sınıflama Standardı ya da orijinal adiyla International Standard Classification of Education (ISCED), ülkelerin eğitim istatistiklerinin uluslararası düzeyde karşılaştırılabilirliğine imkân tanı- yan bir araçtır. ISCED seviyeleri özelinde bakıldığında ise, ISCED 5 kısa dönem yükseköğretim eğitimine, ISCED 6 lisans ya da dengi seviyeye, ISCED 7 yüksek lisans ya da dengi seviyeye ve ISCED 8 doktora ya da dengi seviyeye karşıllk gelmektedir. Dolayısıyla ülkelerin yükseköğretim düzeyi, ISCED 5-8 seviyelerini kapsayan üçüncü düzeyde eğitim olarak kabul görmektedir (OECD/ Eurostat/UNESCO Institute for Statistics, 2015, s.69).

Kümeleme algoritmasında kullanılan ülkeler ise Lüksemburg dışındaki tüm $\mathrm{AB}$ ülkeleri, Norveç, İsviçre ve AB'ye aday ülkeler olan Türkiye, Kuzey Makedonya ve Sırbistan olarak belirlenmiştir. ${ }^{3}$ Bu kapsamda 27 AB ülkesi, 3 AB'ye aday ülke ve 2 ilave ülke olarak veri setine dâhil edilen toplam 32 ülke Tablo 2'de sunulmuștur.

Tablo 2. Kümeleme Algoritmasında Kullanılan Ülkeler4

\begin{tabular}{|c|c|c|}
\hline Kapsam & Ülkeler & Yıl \\
\hline Kurucu Ülkeler & Almanya, Belçika, Fransa, Hollanda, Italya & 1958 \\
\hline Birinci Genişleme & İngiltere, İrlanda, Danimarka & 1973 \\
\hline İkinci Genişleme & Yunanistan & 1981 \\
\hline Üçüncü Genişleme & İspanya, Portekiz & 1986 \\
\hline Dördüncü Genişleme & Avusturya, Finlandiya, Isveç & 1995 \\
\hline $\begin{array}{c}\text { Beşinci Genişleme } \\
\text { Beşinci Genişleme } \\
\text { Devamı }\end{array}$ & $\begin{array}{c}\text { Macaristan, Polonya, Çekya, Slovakya, Slo- } \\
\text { venya, Letonya, Litvanya, Estonya, Malta, } \\
\text { Güney Kıbrı Rum Yönetimi }\end{array}$ & 2004 \\
\hline Altıncı Genişleme & Romanya, Bulgaristan & 2007 \\
\hline Aday Ülkeler & Hürkiye, Kuzey Makedonya, Sırbistan & - \\
\hline Diğer Ülkeler & Norveç, İsviçre & - \\
\hline
\end{tabular}

Kümeleme algoritmasında kullanılan ülkeler düşünüldüğünde, Norveç ve İsviçre dışındaki tüm ülkeler ya $A B$ üyesi ülke ya da AB'ye aday ülke kategorisinde yer almaktadır. Norveç ve İsviçre her ne kadar birliğe üye olmasalarda, eğitim, ekonomi gibi açılardan birliğin etki alanları içerisinde değerlendirilen ülkelerdendir. Dolayısıyla $A B$ üye ve aday ülkelerinin yükseköğretim performansları açısından kümeleme algoritması ile değerlendirilmesinde bu ülkelerin de analize dâhil edilmesi gerekli görülmüştür. Diğer taraftan AB'ye aday ülke olarak analiz kapsamına alınmayan ülkeler (Arnavutluk ve Karadağ) de bulunmaktadır. Bu ülkelerin araştırma kapsamında derlenen değişkenlere ilişkin güncel verilerinin olmaması sebebiyle analize dâhil edilmemiştir.

\subsection{Bulgular}

Araştırmanın yöntem kısmında detaylı olarak anlatılan FCM kümeleme algoritmasının uygulanması sonucunda, ülkeler dört küme içerisinde gruplandırılmıştır. Literatürde küme sayısının belirlenmesine yönelik çeşitli yaklaşımlar bulunmaktadır. Bu çalışmada küme sayısının belirlenmesinde, literatürde sıklıkla kullanılan (8) eşitliğindeki yaklaşım aracıllğıyla küme sayısı dört olarak belirlenmiştir (Tatlıdil, 2002, s.341). Eşitlikte yer alan $n$ ülke sayısını ifade etmekte iken $c$ küme sayısını belirtmektedir. 


$$
c=(n / 2)^{1 / 2}
$$

Araştırma kapsamında farklı küme sayılarına göre oluşturulan kümelerdeki dağılımlar da incelenmiş ve küme sayısı dört olarak seçildiğinde görece homojen bir dağılım elde edildiği de görülmüştür. Kümeleme algoritması sonucunda oluşan kümeler ve ilgili kümelerdeki ülkeler Tablo 3'de verilmiştir.

Tablo 3. Kümeleme Algoritması Sonucunda Oluşan Kümeler ve Illgili Kümelerdeki Ülkeler

\begin{tabular}{|c|c|c|c|}
\hline Küme 1 & Küme 2 & Küme 3 & Küme 4 \\
\hline Danimarka & İngiltere & Litvanya & Kuzey Makedonya \\
\hline İsveç & Polonya & Portekiz & Kıbrıs \\
\hline Norveç & Almanya & İrlanda & Yunanistan \\
\hline Hollanda & İtalya & Slovakya & Sırbistan \\
\hline Avusturya & İspanya & Hırvatistan & Romanya \\
\hline Estonya & Fransa & Bulgaristan & \\
\hline Belçika & Türkiye & Letonya & \\
\hline Finlandiya & & Slovenya & \\
\hline İsviçre & & Çekya & \\
\hline Malta & & & \\
\hline Macaristan & & & \\
\hline
\end{tabular}

Elde edilen bu kümeler özelinde bir üstünlük durumu söz konusu değildir. Dolayısıyla mevcut değişkenler temelinde homojen özellik gösteren ülkeler aynı küme içerisinde değerlendirilirken ayrık özellik gösteren ülkeler ise diğer kümeler içerisinde yer almaktadır. Bu kapsamda elde edilen kümeler ve bu kümelerin içerdikleri ülkeler görsel olarak Şekil 1'de sunulmaktadır.

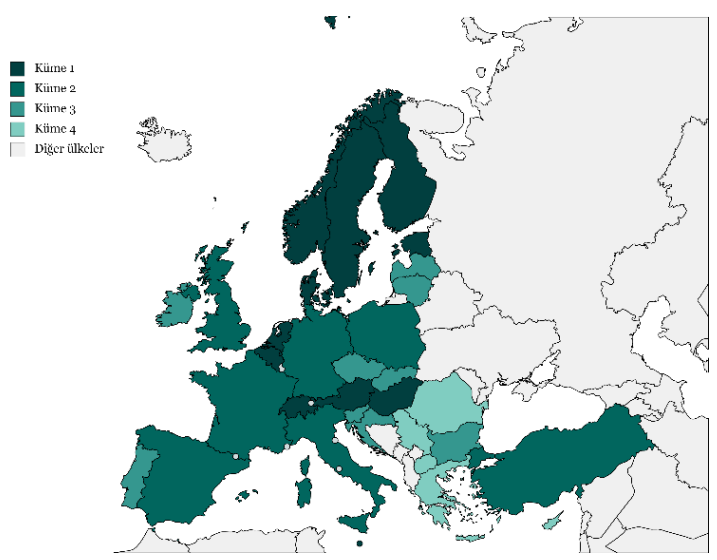

Şekil 1. Kümeleme Algoritmasına Göre Elde Edilen Kümeler

FCM kümeleme algoritması sonuçlarına göre Küme 1'in Danimarka, İsveç, Norveç, Finlandiya gibi oldukça gelişmiş İskandinav ülkeleri kapsadığı görülebilmektedir. Nitekim bu ülkeler kümeleme algoritmasında kullanılan değişkenler bazında en yüksek değerleri alan ülkelerdir. $\mathrm{Bu}$ küme içerisinde dikkat çeken ülkeler olarak Malta ve Macaristan karşımıza çıkmaktadır. Birliğin beşinci genişlemesinde yani 2004 yılında hem Malta hem de Macaristan'ın AB'ye üye oldukları bilinmektedir. Dolayısıyla bu ülkelerin, birliğe üyelik aşamasında yükseköğretimleriyle ilgili benzer politikalar izledikleri ve hayata geçirdikleri söylenebilir. Ayrıca Malta'nın yükseköğretim seviyesinde akademik personel başına düşen öğrenci oranı bakımından en düşük orana sahip olmasından dolayı da ülkenin ilgili küme içerisinde yer aldığı düşünülmektedir.

Küme 2'nin İngiltere, Polonya, Almanya, İtalya, İspanya, Fransa ve Türkiye olmak üzere yedi ülkeden oluştuğu görülmektedir. Bu küme içerisinde değerlendirilen İngiltere, Almanya, İspanya ve Fransa' daki yükseköğretim sistemlerinin oldukça gelişmiş olduğu ve bu yükseköğretim sistemlerinin mezun sayısı, öğretim kadrosu gibi çeşitli performans ölçümlerine dayandığı bilinmektedir (Kabók, Radišić ve Kuzmanović, 2017, s.852). Yükseköğretimin uluslararasılaşması kapsamında Sorbonne Deklerasyonu'nun İngiltere, Almanya, İtalya ve Fransa tarafından 1998'de imzalandığı bilinmektedir. Avrupa yükseköğretim sisteminin uyumlaştırılmasına yönelik çağrıda bulunan bu dört ülkenin de aynı küme içerisinde yer aldığı görülmektedir. Türkiye özelinde düşünüldüğünde ise, kümeleme algoritmasına dâhil edilen tüm ülkelerin yükseköğretimdeki öğretim kadrosu oranı ortalaması 55 iken, ülkemizin bu değişkene ilişkin almış olduğu değer 158'dir. Diğer taraftan günümüzde oldukça önemli bir ölçüt haline gelen teknoloji ve bilgi yoğun sektörlerdeki istihdam değişkeninde ülkelerin ortalaması 8403 iken, ülkemizin bu değişkene ilişkin değerinin de oldukça yüksek (28608) olduğu görülmektedir. Dolay1sıyla yükseköğretim performans değerlendirmesinin birçok değişkeninde ülkemizin ortalamanın üstünde değerlere sahip olması sonucu bu küme içerisinde yer alması beklenen bir durumdur.

Kümeleme algoritması sonucunda oluşan Küme 3'e bakıldığında, bu kümede Litvanya, Portekiz, İrlanda, Slovakya, Hırvatistan, Bulgaristan, Letonya, Slovenya ve Çekya yer almaktadır. Bu küme içerisinde yer alan Litvanya ve Letonya gibi Baltık ülkelerinin her ikisinde de inovasyon odaklı toplum modelinin benimsendiği görülmektedir. Ancak ilgili modelin yükseköğretime entegrasyonu konusunda bu ülkelerin net bir strateji ortaya koyamadıkları da bilinmektedir (Melnikova ve Zaščerinska, 2016, s.101). Dolayısıyla yükseköğretim perspektifinden bakıldığında benzer hedeflere sahip bu ülkelerin aynı küme içerisinde yer alması beklenen bir durumdur. Litvanya ve Letonya gibi birliğe beşinci genişlemede üye olan Slovakya, Slovenya ve Çekya gibi ülkeler de yine bu kümede yer almaktadır. Ayrıca birliğin beşinci genişlemesinin devamında Bulgaristan'ın ve altınca genişlemesinde Hırvatistan'ın da yine aynı küme içerisinde yer aldıkları görülmektedir. Hırvatistan dışında bu küme içerisinde yer alan tüm ülkeler tarafından da 1999 yılında Bologna Süreci’ni imzalandığı bilinmektedir (Hırvatistan ilgili belgeyi 2001 yılında imzalamıștır). Temeli 1998'deki Sorbonne Deklerasyonu'na dayanan Bologna Süreci, yükseköğretimde öğrenci ve öğretim kadrosu hareketliliğinin geliştirilmesi amacıyla ilgili araçların uygulanmasını gerektiren bir reform sürecini ifade etmektedir (Bulajeva ve Hogan-Brun, 2014, s.319). Dolayısıyla yükseköğretimin 
Avrupa düzeyinde uluslararasılaștırılması kapsamında bu belgeyi imzalayan ve birliğe benzer zamanlarda üye olan bu ülkelerin de aynı küme içerisinde yer almaları beklenen bir durum olarak karşımıza çıkmaktadır.

Son küme olan Küme 4'de Kuzey Makedonya, Kıbrıs, Yunanistan, Sirbistan ve Romanya bulunmaktadır. Yükseköğretim performansları bakımından bu kümede yer alan ülkelerin, Güney Avrupa ve Doğu Avrupa'da yer alan komşu ülkeler oldukları görülebilmektedir. Avrupa'nın diğer ülkelerinin yükseköğretimlerinde performansa dayalı bir model benimsenmekte iken bu kümede yer alan ülkelerin yükseköğretimlerinde bu tarz modellerin gereklerinin tam olarak yerine getirilmediği söylenebilmektedir. İlgili ülkelerdeki yükseköğretimin ideal özerklikten uzak olması, politik baskılara maruz kalması ve bu durumların da performansa dayalı modelle bağdaşmadığ görülmektedir (Tomusk, 2010, s.175; Kabók vd., 2017, s.853). Dolayısıyla bu son kümelenmedeki ülkelerin yükseköğretimlerindeki baskıların ya da dayatılan reformların kaldırılması, ilgili ülkelerin yükseköğretimlerinin diğer Avrupa ülkelerindeki yükseköğretimlere yakınsamasını sağlayacaktır.

Yukarıda kümeleme algoritması sonucunda oluşan dört kümede yer alan ülkelere ilișkin yapılan değerlendirmelerin ardından bu kümelerin kapsamış oldukları ülke sayısı, küme içi uzaklıkları ve kümelerin ağırlık merkezine olan uzaklıklarına ilișkin detaylı bilgiler Tablo 4'de verilmiştir.

Tablo 4. Kümeleme Algoritması Sonucunda Oluşan Kümelere İlişkin Bilgiler

\begin{tabular}{|l|c|c|c|c|c|}
\hline & Boyut & $\begin{array}{c}\text { Küme içi } \\
\text { uzaklık }\end{array}$ & $\begin{array}{c}\text { Ağırlık merke- } \\
\text { zine minimum } \\
\text { uzaklık }\end{array}$ & $\begin{array}{c}\text { Ağırlık merkezine Ağırlık merke- } \\
\text { maksimum } \\
\text { uzaklık }\end{array}$ & $\begin{array}{c}\text { zine ortalama } \\
\text { uzaklık }\end{array}$ \\
\hline Küme 1 & 11 & 0.058 & 0.008 & 0.209 & 0.048 \\
\hline Küme 2 & 7 & 0.019 & 0.009 & 0.095 & 0.043 \\
\hline Küme 3 & 9 & 0.026 & 0.009 & 0.102 & 0.042 \\
\hline Küme 4 & 5 & 0.019 & 0.027 & 0.098 & 0.057 \\
\hline
\end{tabular}

Kümeleme algoritmasının temel prensibi, küme içindeki veri noktalarının küme merkezine olan uzaklıkları minimize edilirken; küme merkezleri arasındaki uzaklıkların maksimize edilmesine dayanmaktadır (Ross, 2010: 354). Bu prensip doğrultusunda, Küme 1 ve Küme 3'ün diğer kümelere göre daha yüksek küme içi uzaklık değerine ve ağılık merkezine olan ortalama uzaklık bakımından da daha yüksek bir değere sahip oldukları görülebilmektedir. Dolayısıyla Küme 2 ve Küme 4'ün diğer iki kümeye göre daha az küme içi uzaklık ürettiği ve yükseköğretim performanslarının ölçülmesinde kullanılan değişkenler bazında görece daha homojen oldukları söylenebilmektedir.

\section{TARTIȘMA, SONUÇ VE ÖNERILER}

Ülkelerin sosyo-ekonomik ve kültürel gelişimlerinde yükseköğretim sistemlerinin rolü yadsınamayacak bir öneme sahiptir. Çünkü ülkeler çağın gereksinimlerine cevap verebilmek adına yükseköğretim sistemlerini şekillendirmekte ve değiştirmektedirler. Tarihsel olarak bakıldığında, özellikle Avrupa'daki yükseköğretim sistemleri, bilgiye dayalı bir toplumun yaratılmasında temel eğitim kurumları olarak görülmektedir (Sursock, Smidt ve Davies, 2010, s.4).

Günümüzdeki uluslararası eğilimler ya da ulusal politikalar kapsamında düşünüldüğünde, bilgiye dayalı bir toplumun yaratılması dinamik bir süreci gerektirmektedir. Bu dinamik süreçte yükseköğretim sistemlerinin amaçlarının iyi belirlenmesi, bu sistemlerin belirli bir kalite düzeyine ulaştırılması ve bu kalite düzeyinin de sürdürülebilirliğinin sağlanması oldukça önemlidir. Tüm bu hedeflerin gerçekleştirilmesi için öncelikle ülkelerin yükseköğretim performansları bakımından mevcut durumlarının bilinmesi gerekmektedir. Bu sorunlara cevap verebilmek adına çalışmada, ülkelerin yükseköğretim performanslarına göre kümelenmesi ve bu kümeler aracılığıyla ülkelerin yükseköğretim plan ve politikalarının karşılaştırmalı olarak değerlendirilmesi amaçlanmıştır. Bu amaçla FCM kümeleme algoritmasına başvurulmuştur. FCM kümeleme algoritması literatürde sıklıkla kullanılan kümeleme algoritmalarındandır ve bu algoritmanın diğer klasik kümeleme algoritmalarına kıyasla iyi performans gösterdiği bilinmektedir. Diğer taraf$\tan$ FCM algoritması, küme sayısının bilindiği ya da en azından belirlenebildiği şeklinde birtakım kısıtlamalara sahiptir. Bu başlangıç parametresinin otomatik olarak belirlenebilmesi amacıyla literatürde FCM'nin çeșitli güncellenmiş versiyonları bulunmaktadır.

Çalışmanın uygulama aşamasında ülkelerin eğitim, istihdam ve ekonomi kategorilerinde seçilen altı değişkene ait değerleri kullanılarak bu ülkelerin yükseköğretim performanslarının FCM kümeleme algoritmasında değerlendirilmesinde dört küme elde edilmiştir. Bu kümelenmeler düşünüldügünde, $\mathrm{AB}$ üyesi ve Bologna Süreci'ni imzalayan ülkelerin yükseköğretimlerinde aslında uluslararasılaşması konusunda birtakım reform çalışmalarının kabul edildiği ve uygulandığı söylenebilmektedir (EHEA, 2015). Türkiye Bologna Süreci'ni 2001 yılında imzalayan bir ülke olarak, ülkemiz yükseköğretiminde de Avrupa standartları kabul edilmiş ve benimsenmiștir. Nitekim seçilen değişkenler aracılığıyla yapılan kümeleme algoritması sonucunda ülkemiz İngiltere, Almanya, Fransa gibi önemli Avrupa ülkeleri ile aynı kümede yer almıștır. Bu durum bize mezun öğrenci sayısı, akademik kadro, sektörler bazında istihdam, Ar-Ge faaliyetleri ve eğitim harcamaları konusunda kümedeki diğer ülkelerle benzer nitelikler taşıdığımızı göstermektedir. Böyle bir sonucun ortaya çıkmasında Bologna sürecine uyuma yönelik yapılan faaliyetlerin etkisi büyük olmuștur. Aynı zamanda ilgili kümedeki ülkelerin ekonomik açıdan gelişmiş ülkeler kategorisinde oldukları da görülebilmektedir. Ekonomik gelişmenin temelindeki nitelikli insan gücü dikkate alındığında, ülkemizin de içerisinde yer 
aldığı kümedeki diğer ülkelerle aynı ekonomik seviyeye sahip olabilmesi için yapması gereken daha önce ifade edilen temel sorunların aşılmasıyla mümkün olacaktır. Ayrıca yükseköğretimimizin sürekli olarak uluslararası standartlara uyarlanması ve ulusal düzeyde kalite güvencesi sistemlerimizin geliştirilmesi de bu kapsamda oldukça fayda sağlayacaktır. Gelecekteki çalışmalarda, sadece 32 ülke için yapılan bu çalışmanın daha çok ülkeyi barındıracak şekilde genişletilmesinin ve başlangıç parametrelerinin de otomatik belirlenmesinin sağlayarak güncellenmesi planlanmaktadır.

\section{KAYNAKÇA}

Adem, M. (1982). Kalkınma planlarında eğitimimizin hedefleri ve finansmanı. Ankara: Sevinç Matbaası.

Al Kindhi, B., Sardjono, T. A., Purnomo, M. H., \& Verkerke, G. J. (2019). Hybrid k-means, fuzzy c-means, and hierarchical clustering for DNA hepatitis c virus trend mutation analysis. Expert Systems with Applications, 121, 373-381.

Bezdek, J. C. (1981). Fuzzy mathematics in pattern classification (PhD Dissertation). Applied Mathematics Center, Cornell University, Ithaca, NY.

Bulajeva, T., \& Hogan-Brun, G. (2014). Internationalisation of higher education and nation building: Resolving language policy dilemmas in Lithuania. Journal of Multilingual and Multicultural Development, 35(4), 318-331.

Büyükgöze, H., \& Özdemir, M. (2016). Avrupa Yükseköğretim Alanı (AYA) Yükseköğretime erişimi ve katılımı genişletme politikalarının değerlendirilmesi. Yükseköğretim Dergisi, 6(1), 40-46.

Çalışkan, A. (2001). Sosyal refahın sağlanmasında devletin etkinliği ve Türkiye örneği (Yayımlanmamış doktora Tezi). Dokuz Eylül Üniversitesi Sosyal Bilimler Enstitüsü, İzmir.

Çavdar, A. (1994). Dünya'da ve Türkiye'de bilim, etik ve üniversite. İçinde Türkiye bilimler akademisi (ss.3-4). Ankara: TÜBA.

Çömlekçi, N. (1971). Türkiye'nin iktisadi kalkınmasında eğitimin rolü. Ankara: Sevinç Matbaası.

Deem, R., Mok, K. H., \& Lucas, L. (2008). Transforming higher education in whose image? Exploring the concept of the 'world-class' university in Europe and Asia. Higher Education Policy, 21(1), 83-97.

Dunn, J. C. (1973). A fuzzy relative of the ISODATA process and its use in detecting compact well-separated clusters. Journal of Cybernetics 3, 32-57.

European Higher Education Area (2015). European higher education area and bologna process. https://ehea.info/ Erişim tarihi: 15.02.2021.

Gedikoğlu, T. (2005). Avrupa Birliği sürecinde Türk eğitim sistemi: sorunlar ve çözüm önerileri. Mersin Üniversitesi Eğitim Fakültesi Dergisi, 1(1), 66-80.

Gemmell, N. (1998). Reviewing the new growth literature. New Political Economy, 3(1), 129-134.

Ghosh, S., \& Dubey, S. K. (2013). Comparative analysis of k-means and fuzzy c-means algorithms. International Journal of Advanced Computer Science and Applications, 4(4), 35-39. on ranking of higher education institutions. http://www. ihep.org/sites/default/files/uploads/docs/pubs/berlinprinciplesranking.pdf Erişim tarihi: 08.02.2021.

Izakian, H., \& Abraham, A. (2011). Fuzzy c-means and fuzzy swarm for fuzzy clustering problem. Expert Systems with Applications, 38(3), 1835-1838.

Joumady, O., \& Ris, C. (2005). Performance in European higher education: a non-parametric production frontier approach. Education Economics, 13(2), 189-205.

Kabók, J., Radišić, S., \& Kuzmanović, B. (2017). Cluster analysis of higher-education competitiveness in selected European countries. Economic Research, 30(1), 845-857.

Küçükcan, T., \& Gür, B. S. (2010). Türkiye'de yükseköğretim karşılaştırmalı bir analiz. Ankara: Seta Yayınları.

Melnikova, J., \& Zaščerinska, J. (2016). Integration of entrepreneurship into higher education (educational sciences) in Lithuania and Latvia: focus on students' entrepreneurial competencies. Regional Formation and Development Studies, 1(18), 100-109.

OECD/Eurostat/UNESCO Institute for statistics (2015). "Tertiary education". In ISCED 2011 Operational Manual: guidelines for classifying national education programmes and related qualifications (s.69). Paris: OECD Publishing.

Ross, T. J. (2010). Fuzzy logic with engineering applications (3rd ed). United Kingdom: John Wiley \& Sons, Ltd.

Sefidian, A. M., \& Daneshpour, N. (2019). Missing value imputation using a novel grey based fuzzy c-means, mutual information based feature selection, and regression model. Expert Systems with Applications, 115, 68-94.

Sorbonne Joint Declaration. 1998. Joint declaration on harmonisation of the architecture of the European higher education system. http://www.bologna-berlin2003.de/pdf/Sorbonne_declarati on.pdf Erişim tarihi: 13.02.2021.

Sursock, A., Smidt, H., \& Davies, H. (2010). Trends 2010: a decade of change in European higher education. Brussels: European University Association.

Tatlıdil, H. (2002). Uygulamalı çok değişkenli istatistiksel analiz. Ankara: Ziraat Matbaacılık.

Tomusk, V. (2000). When east meets west: decontextualizing the quality of East European higher education. Quality in Higher Education, 6(3), 175-185. 